\title{
First Evidence of Proline Acting as a Bifunctional Catalyst in the Baylis- Hillman Reaction Between Alkyl Vinyl Ketones and Aryl Aldehydes
}

\author{
Michelangelo Gruttadauria, ${ }^{*[a]}$ Francesco Giacalone, ${ }^{[a]}$ Paolo Lo Meo, ${ }^{[a]}$ \\ Adriana Mossuto Marculescu, ${ }^{[a]}$ Serena Riela, ${ }^{[a]}$ and Renato Noto ${ }^{[a]}$
}

Keywords: Aldehydes / Baylis-Hillman reactions / Organocatalysis / Proline / Reaction mechanisms / Semi-empirical calculations

Proline in the presence of sodium hydrogen carbonate has been found to be an effective catalyst for the Baylis-Hillman reaction between methyl or ethyl vinyl ketone and aryl aldehydes. Screening of several amine catalysts showed that an ionizable carboxylic function directly linked to the secondary amine catalyst plays an important role in the synthesis of the desired product in good yield. The data obtained has allowed us to suggest, for the first time, that proline, sarcosine, pipec- olinic acid and homoproline may act as bifunctional catalysts via a bicyclic enaminolactone species as intermediate. Quantum-mechanical calculations (PM3/COSMO and ab initio 3$21 \mathrm{G} / \mathrm{COSMO}$ ) support this mechanism and give more insight into the role of hydrogen carbonate.

(ङ Wiley-VCH Verlag GmbH \& Co. KGaA, 69451 Weinheim, Germany, 2008)

\section{Introduction}

The Baylis-Hillman reaction is a versatile and atom-economical carbon-carbon bond-forming reaction which has attracted huge interest in the scientific community. ${ }^{[1-6]}$ This reaction involves the amine- (or phosphane-)catalysed ${ }^{[7]}$ addition of an aldehyde to an activated alkene, such as alkyl vinyl ketones, alkyl (aryl) acrylates, acrylonitrile and vinyl sulfones. Scheme 1 shows the commonly accepted mecha-

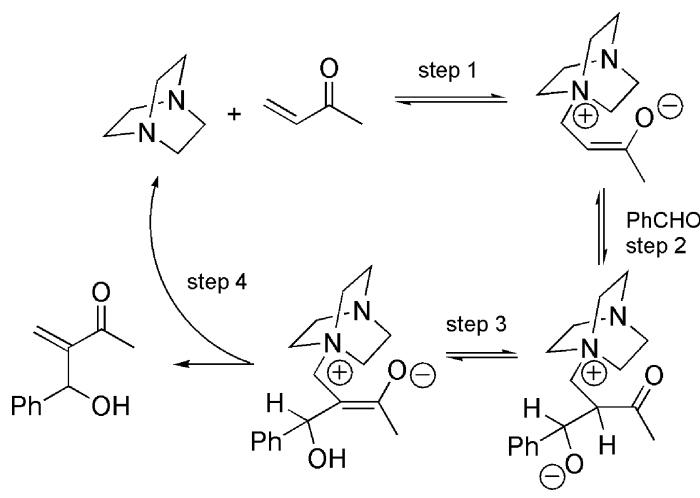

Scheme 1. DABCO-catalysed Baylis-Hillman reaction.

[a] Dipartimento di Chimica Organica "E. Paternò", Università di Palermo,

Viale delle Scienze, Pad. 17, 90128, Palermo, Italy

Fax: +39-091-596825

E-mail: mgrutt@unipa.it

Supporting information for this article is available on the WWW under http://www.eurjoc.org or from the author. nism for the model Baylis-Hillman reaction between methyl vinyl ketone and benzaldehyde in the presence of DABCO as catalyst.

The first step involves the reversible conjugate addition of the nucleophilic amine to the $\alpha, \beta$-unsaturated ketone to generate an enolate. The second step involves the nucleophilic attack of the enolate on the aldehyde to generate a zwitterionic intermediate. Finally, proton migration (step 3) and elimination (step 4) afford the product and regenerate the amine catalyst. Protic solvents are known to accelerate the reaction, whereas in the absence of any proton donor the reaction shows autocatalysis. ${ }^{[8]}$ It has been proposed that the product can act as a hydrogen-bond donor. Thus, in the initial stage of the reaction, step 3 is the rate-limiting step. As the product concentration increases, the protontransfer mechanism becomes efficient and step 2 becomes rate-limiting. Aggarwal et al. proposed that in the presence of a protic species (product or solvent) the zwitterionic intermediate is involved in a proton-transfer reaction that facilitates the formation of the product (Scheme 2) ${ }^{[9]}$

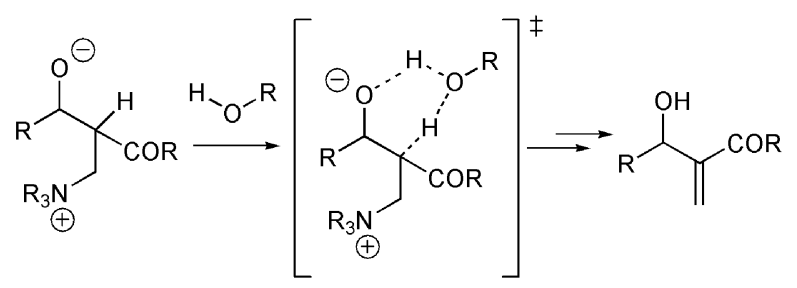

Scheme 2. Role played by protic solvents in the Baylis-Hillman reaction. ${ }^{[9]}$ 
McQuade and co-workers proposed the formation of a hemiacetal intermediate (Scheme 3). They determined that the rate-determining step was second order in the aldehyde and first order in DABCO and the acrylate. ${ }^{[10,11]}$<smiles>COC(=O)C(CN1CCN2CCC1C2)C([O-])Br</smiles><smiles>COC(=O)C(CN1CCCCC1)(CN1CCN2CCC1CC2)C(Br)OC([O-])[O-]</smiles><smiles>[B]OC(Br)OC(Br)C(=C[N+]12CCC(CC1)CC2)C(=O)OC</smiles>

Scheme 3. McQuade's Baylis-Hillman mechanism..$^{[10,11]}$

In addition to DABCO, several tertiary amine catalysts have been successfully employed in various Baylis-Hillman reactions. Among them, imidazole was found to be a good catalyst in neutral aqueous media. ${ }^{[12]}$ Imidazole was used in stoichiometric amounts. Later, a rate acceleration of both imidazole- and other azole-promoted Baylis-Hillman reactions was reported in mildly basic water solution $(1 \mathrm{M}$ $\left.\mathrm{NaHCO}_{3}\right) .{ }^{[13,14]}$ The $\mathrm{pH}$ effect on the catalytic activity was attributed to the increased concentration of unprotonated imidazole which acts as a more efficient nucleophile. Shi et al. reported that L-proline $(30 \mathrm{~mol}-\%)$ and imidazole (30 mol- $\%$ ) catalysed the Baylis-Hillman reaction between methyl vinyl ketone and several substituted benzaldehydes. ${ }^{[15]}$ No reaction occurred when only proline or imidazole were used. More recently it was reported that the above reaction can be carried out by using a smaller amount of both catalysts $(10 \mathrm{~mol}-\%)$. Moreover, it was claimed that water plays a crucial role in the acceleration of the reaction. A 9:1 dimethylformamide/water mixture was found to be the best solvent for this reaction. ${ }^{[16]}$ The following mechanism has been postulated for the reaction (Scheme 4): the intermediate $\alpha, \beta$-unsaturated iminium ion is formed by the reaction between methyl vinyl ketone (MVK) and proline which subsequently undergoes nucleophilic attack by imidazole. The resulting enamine reacts with the aldehyde to give, after elimination of imidazole and hydrolysis of the iminium ion, the Baylis-Hillman adduct. No enantioselectivity was observed under these reaction conditions. However, enantioselective intramolecular Baylis-Hillman reactions have been reported. ${ }^{[17,18]}$ Moreover, enantioselectivity was observed when a peptide was used in place of imidazole ${ }^{[19]}$ or by using proline and chiral tertiary amines. ${ }^{[20-22]}$ L-Proline proved to be an excellent catalyst in the aza-Morita-Baylis-Hillman reaction. ${ }^{[23,24]}$

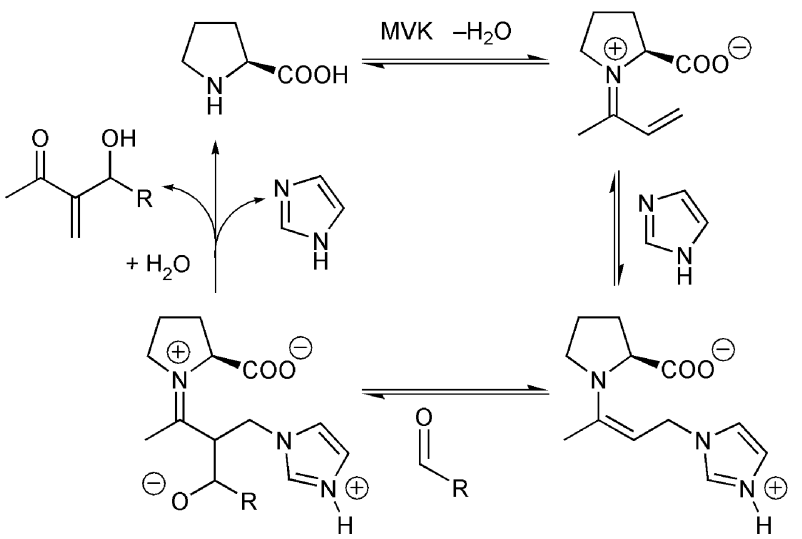

Scheme 4. Proposed mechanism for the proline/imidazole-catalysed Baylis-Hillman reaction. ${ }^{[15]}$

Recently we have focused our research efforts on organocatalysis and, in this context, proline is a powerful organocatalyst. We have mainly devoted our studies to the immobilization and recovery of proline. ${ }^{[25-28]}$ However, during our study of Baylis-Hillman reactions we envisaged the possibility of an improvement of the above reaction catalysed by proline in homogeneous systems.

\section{Results}

We first checked if by using only L-proline (10 mol- $\%)$ in $\mathrm{DMF} / \mathrm{H}_{2} \mathrm{O}$ (9:1) the reaction between MVK and 4-nitrobenzaldehyde takes place. No product was observed after $16 \mathrm{~h}$ when the reaction was carried out at room temperature and less than $5 \%$ of the adduct was obtained after $16 \mathrm{~h}$ at $40^{\circ} \mathrm{C}$. Thus, a co-catalyst was needed to produce the adduct. As the use of $\mathrm{NaHCO}_{3}$ gave rise to a rate acceleration in the imidazole-promoted reactions, we repeated the experiment using L-proline (10 mol- $\%$ ) and $\mathrm{NaHCO}_{3}(25 \mathrm{~mol}-$ $\%)$ in $\mathrm{DMF} / \mathrm{H}_{2} \mathrm{O}(9: 1)$ at both 25 and $40{ }^{\circ} \mathrm{C}$. At room temperature we observed $94 \%$ conversion and $85 \%$ yield, whereas at $40{ }^{\circ} \mathrm{C}$ we noted complete conversion and $92 \%$ yield. No enantioselectivity was observed in either case. ${ }^{[29]}$ We used these latter conditions to investigate the reactions of a series of aryl aldehydes. The data obtained are reported in Table 1. High isolated yields were obtained with electronwithdrawing substituents in the 2-, 3- and 4-positions. The more hindered 2,6-dichlorobenzaldehyde required a longer reaction time. In several cases conversions were almost quantitative (99\%). With 4-methylbenzaldehyde a modest yield was obtained after a prolonged reaction time whereas benzaldehyde and 3-methoxybenzaldehyde gave the corresponding adducts in moderate yields. No reaction was observed after $20 \mathrm{~h}$ when cyclohexanecarbaldehyde was used. The reactions were carried out using $1 \mathrm{mmol}$ of aldehyde and $3 \mathrm{mmol}$ of MVK in $1 \mathrm{~mL}$ of $\mathrm{DMF} / \mathrm{H}_{2} \mathrm{O}(9: 1)$. In addition to MVK, ethyl vinyl ketone (EVK) was also employed. The reactions were also scaled up to $5 \mathrm{mmol}$ of aldehyde. Again, high isolated yields were obtained (Table 1, entries 18-21). 
Table 1. Baylis-Hillman reaction with a series of aldehydes.

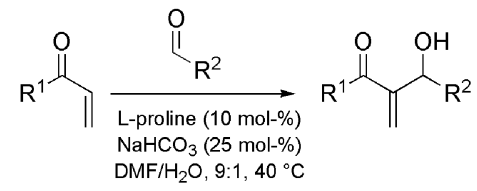

\begin{tabular}{|c|c|c|c|c|c|}
\hline Entry & $\mathrm{R}^{1}$ & $\mathrm{R}^{2}$ & Time $[\mathrm{h}]$ & $\%$ Conv.$^{[a]}$ & $\begin{array}{l}\% \text { Isol. } \\
\text { yield }[\mathrm{b}]\end{array}$ \\
\hline 1 & $\mathrm{Me}$ & $4-\mathrm{O}_{2} \mathrm{~N}-\mathrm{C}_{6} \mathrm{H}_{4}$ & 16 & $>99$ & 92 \\
\hline 2 & $\mathrm{Me}$ & $3-\mathrm{O}_{2} \mathrm{~N}-\mathrm{C}_{6} \mathrm{H}_{4}$ & 16 & 88 & 77 \\
\hline 3 & $\mathrm{Me}$ & 4-NC- $\mathrm{C}_{6} \mathrm{H}_{4}$ & 16 & 99 & 81 \\
\hline 4 & $\mathrm{Me}$ & $4-\mathrm{F}_{3} \mathrm{C}-\mathrm{C}_{6} \mathrm{H}_{4}$ & 16 & 99 & 93 \\
\hline 5 & $\mathrm{Me}$ & $4-\mathrm{Br}-\mathrm{C}_{6} \mathrm{H}_{4}$ & 16 & 80 & 76 \\
\hline 6 & $\mathrm{Me}$ & $3-\mathrm{Br}^{-} \mathrm{C}_{6} \mathrm{H}_{4}$ & 17 & 76 & 70 \\
\hline 7 & $\mathrm{Me}$ & 4-Cl- $\mathrm{C}_{6} \mathrm{H}_{4}$ & 19 & 77 & 72 \\
\hline 8 & $\mathrm{Me}$ & $3-\mathrm{Cl}-\mathrm{C}_{6} \mathrm{H}_{4}$ & 19 & 84 & 79 \\
\hline 9 & $\mathrm{Me}$ & $2-\mathrm{CN}-\mathrm{C}_{6} \mathrm{H}_{4}$ & 19 & 91 & 84 \\
\hline 10 & $\mathrm{Me}$ & $2-\mathrm{Cl}-\mathrm{C}_{6} \mathrm{H}_{4}$ & 19 & 93 & 77 \\
\hline 11 & $\mathrm{Me}$ & $2-\mathrm{F}-\mathrm{C}_{6} \mathrm{H}_{4}$ & 17 & 95 & 78 \\
\hline 12 & $\mathrm{Me}$ & 2-furyl & 48 & 73 & 59 \\
\hline 13 & $\mathrm{Me}$ & $2-\mathrm{Cl}-5-\mathrm{O}_{2} \mathrm{~N}-\mathrm{C}_{6} \mathrm{H}_{3}$ & 17 & $>99$ & 77 \\
\hline 14 & $\mathrm{Me}$ & $2,6-\mathrm{Cl}_{2}-\mathrm{C}_{6} \mathrm{H}_{3}$ & 48 & 95 & 90 \\
\hline 15 & $\mathrm{Me}$ & $4-\mathrm{H}_{3} \mathrm{C}-\mathrm{C}_{6} \mathrm{H}_{4}$ & 120 & 42 & 32 \\
\hline 16 & $\mathrm{Me}$ & $\mathrm{Ph}$ & 68 & 55 & 51 \\
\hline 17 & $\mathrm{Me}$ & $3-\mathrm{H}_{3} \mathrm{CO}-\mathrm{C}_{6} \mathrm{H}_{4}$ & 72 & 69 & 59 \\
\hline 18 & Et & $4-\mathrm{O}_{2} \mathrm{~N}-\mathrm{C}_{6} \mathrm{H}_{4}$ & 17 & 96 & 80 \\
\hline 19 & Et & $4-\mathrm{NC}-\mathrm{C}_{6} \mathrm{H}_{4}$ & 17 & 90 & 81 \\
\hline 20 & Et & $4-\mathrm{F}_{3} \mathrm{C}-\mathrm{C}_{6} \mathrm{H}_{4}$ & 17 & 90 & 80 \\
\hline 21 & Et & $2-\mathrm{Cl}-\mathrm{C}_{6} \mathrm{H}_{4}$ & 17 & 90 & 77 \\
\hline
\end{tabular}

[a] Determined by ${ }^{1} \mathrm{H}$ NMR spectroscopy. [b] After column chromatography.

In order to gain a deeper insight into the role of L-proline in this reaction, we carried out the reaction between MVK and 4-nitrobenzaldehyde using different catalysts. The results are reported in Table 2 . We initially checked if simple pyrrolidine catalyses the reaction. However, after $16 \mathrm{~h}$ at $40{ }^{\circ} \mathrm{C}$ no aldehyde was recovered, but a complex mixture of products was observed (Table 2 , entry 2 ). At room temperature we obtained a complex mixture of products in which the desired adduct was detected in about $8 \%$ yield (Table 2 , entry 3 ). In order to carry out the reaction under more closely comparable (less basic) conditions with respect to pyrrolidine, we used an equimolar mixture of pyrrolidine and acetic or bromoacetic acid (Table 2, entries 4 and 5, respectively). In these cases the reactions also gave complex mixtures of products. The desired adduct was detected in $16 \%$ yield. The use of prolinol gave a similar result (Table 2, entry 6), whereas L-proline methyl ester gave poor conversion as well as a complex mixture of products (Table 2, entry 7).

High conversions were obtained with sarcosine, pipecolinic acid and L-homoproline, but isolated yields decreased in the same order (Table 2, entries 8-10). In particular, sarcosine gave the adduct in a comparable yield to L-proline. The reaction carried out in the absence of an amine catalyst also gave a complex mixture of products in which the desired adduct was recovered in low yield $(9 \%$, Table 2 , entry 11). The reactions were then repeated with L-proline, sarcosine, pipecolinic acid and L-homoproline, quenched af-
Table 2. Screening of amine catalysts in the Baylis-Hillman reaction between MVK and 4-nitrobenzaldehyde.

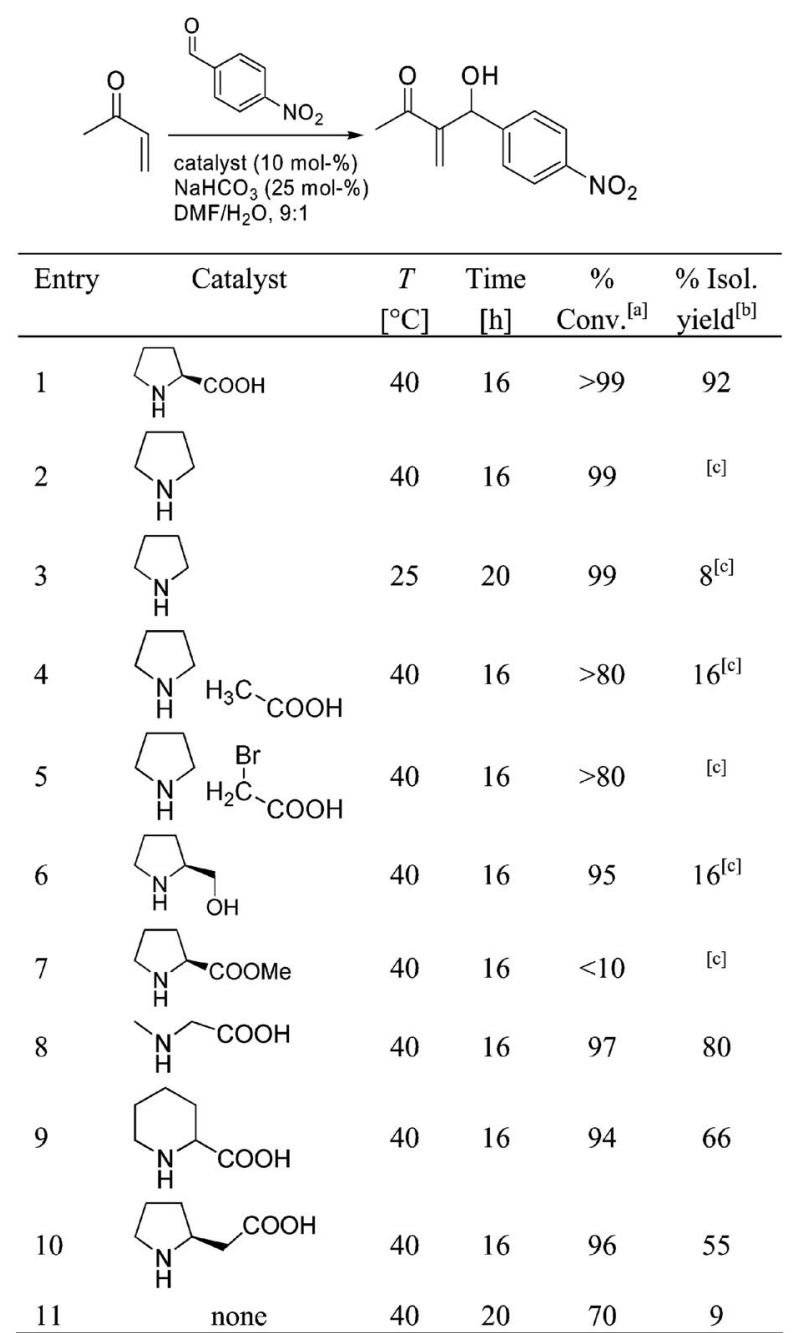

[a] Determined by ${ }^{1} \mathrm{H}$ NMR spectroscopy. [b] After column chromatography. [c] Complex mixture of byproducts.

ter $2 \mathrm{~h}$ and the conversion evaluated by ${ }^{1} \mathrm{H}$ NMR (Table 3 ). In addition to these amino acids, 3- and 4-piperidinecarboxylic acids were used. L-Proline was found to be the most efficient catalyst. Moreover, by assuming that reaction conversions obeyed a pseudo-first-order kinetic law, on the grounds of data reported in Table 3, we were also able to estimate the relative reactivities of the different catalysts (Table 3; the reactivity of proline was taken as a reference) according to Equation (1).

$k_{\mathrm{cat}} / k_{\mathrm{PRO}}=[\ln (1-\operatorname{conv} \% / 100)]_{\mathrm{cat}} /[\ln (1-\operatorname{conv} \% / 100)]_{\mathrm{PRO}}$

The kinetics of the reaction catalysed by L-proline was also followed by ${ }^{1} \mathrm{H} \mathrm{NMR}$ with the aim to ascertain the order of the reaction with respect to the organic catalyst. The process was carried out in $\left[\mathrm{D}_{6}\right] \mathrm{DMSO} / \mathrm{D}_{2} \mathrm{O}(9: 1)$ in an NMR tube at $40{ }^{\circ} \mathrm{C}$ with magnetic stirring. At regular intervals, the magnet was removed and the ${ }^{1} \mathrm{H}$ NMR spectrum recorded. Three reaction systems were examined: 10, 7.5 and $5 \mathrm{~mol}-\%$ of L-proline. We followed the pseudo-first-or- 
Table 3. Relative reactivities of amino acids.

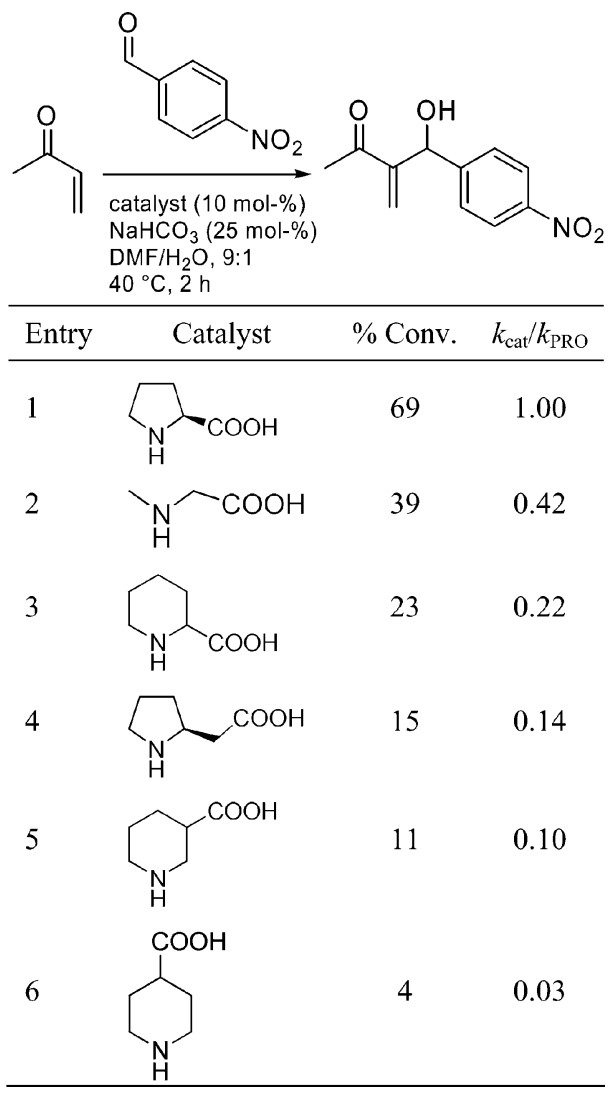

der disappearance of the aldehyde reactant (Figure 1, Table 4). Neither intermediates nor byproducts were detected in significant amounts. ${ }^{[30]}$ Thus, from the experimental data we were able to calculate the relevant pseudo-firstorder rate constants. Notably, because the pseudo-first-order rate constants appear to be linearly dependent on the catalyst concentration (Figure 2, Table 5), the results clearly indicate that only one proline molecule is involved along the reaction coordinate before the rate-limiting step.

These observations allowed us to consider the actual reaction mechanism. The data clearly reveal some interesting facts. To begin with, the presence of an ionizable carboxylic function directly linked to the secondary amine catalyst seems to be a necessary condition to obtain the desired product in good yield. This suggested to us that the reaction might proceed via an intermediate bicyclic enaminolactone species (Scheme 5). ${ }^{[31]}$ This intermediate is very likely formed by the spontaneous cyclization of the zwitterionic iminium species which originates from the attack of the secondary amino acid on MVK.

The formation of an enaminolactone species easily explains the order of reactivity of the amino acid catalysts reported in Table 3. As a matter of fact, the effectiveness of the different amino acids examined as catalysts clearly appears to be affected by entropic factors, as a function of the relevant intramolecular rotational degrees of freedom and

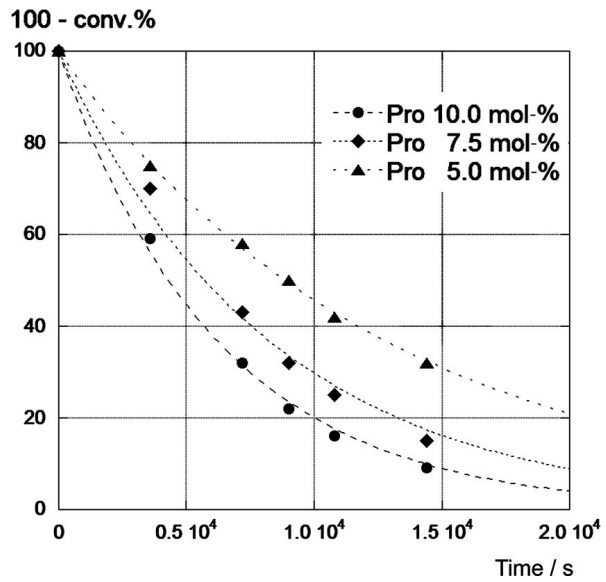

Figure 1. Pseudo-first-order kinetics for the aldehyde in the BaylisHillman reaction.

Table 4. Amount of 4-nitrobenzaldehyde determined in the kinetic experiments (see Figure 1).

\begin{tabular}{lcccc}
\hline Entry & Time $[\mathrm{h}]$ & $\begin{array}{c}\text { \% Aldehyde } \\
\text { Proline } \\
10 \text { mol- } \%\end{array}$ & $\begin{array}{c}\text { Proline } \\
7.5 \text { mol- } \%\end{array}$ & $\begin{array}{c}\text { Proline } \\
5.0 \text { mol- } \%\end{array}$ \\
\hline 1 & 0 & 100 & 100 & 100 \\
2 & 1 & 59 & 70 & 75 \\
3 & 2 & 32 & 43 & 58 \\
4 & 2.5 & 22 & 32 & 50 \\
5 & 3 & 16 & 25 & 42 \\
6 & 4 & 9 & 15 & 32 \\
\hline
\end{tabular}

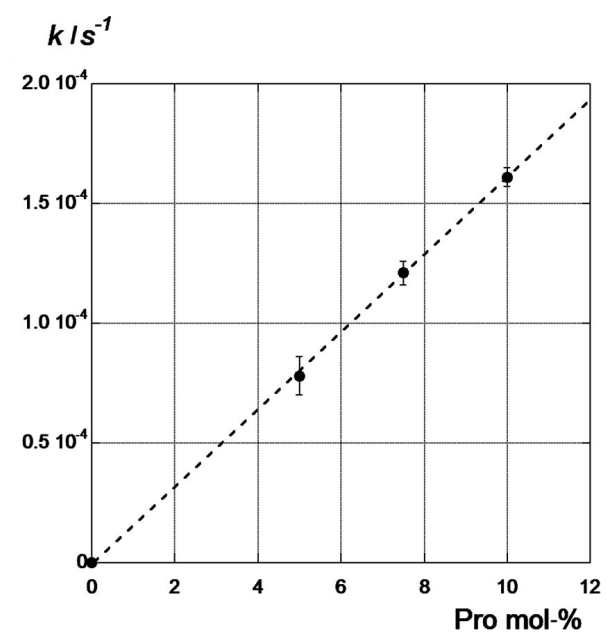

Figure 2. Pseudo-first-order rate constants as a function of catalyst concentration.

Table 5. Variation of the pseudo-first-order kinetic constants with proline concentration (see Figure 2).

\begin{tabular}{lcc}
\hline Entry & $\%$ Proline & $k\left[10^{-4} \mathrm{~s}^{-1}\right]$ \\
\hline 1 & 5.0 & $0.78 \pm 0.08$ \\
2 & 7.5 & $1.21 \pm 0.05$ \\
3 & 10.0 & $1.61 \pm 0.04$ \\
\hline
\end{tabular}




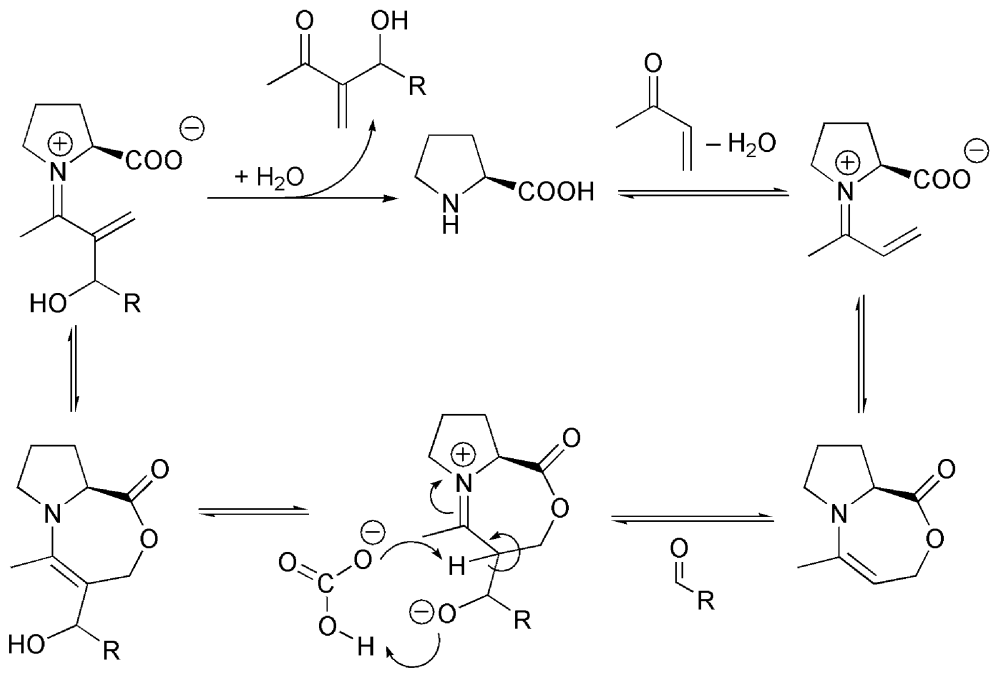

Scheme 5. Proposed mechanism for the proline/ $\mathrm{NaHCO}_{3}$-catalysed Baylis-Hillman reaction.

on the mutual distance between the nitrogen atom and the carboxylic group. By using the best catalyst proline as a reference, the less constrained pipecolinic acid is clearly a poor catalyst and a further decrease in effectiveness is observed with the pipecolinic acid isomers on increasing the distance between the functional amino and carboxy groups (Table 3, entries 5 and 6). Noticeably, sarcosine is quite effective despite its open-chain structure which suggests that any possible unfavourable effect arising from its conformational freedom is somehow counterbalanced by the fact that the corresponding enaminolactone is monocyclic, and thus its formation is less subject to angular strain effects. Homoproline is consistently more effective than 3-piperidinecarboxylic acid, but much less effective than proline.

A referee suggested a different mechanism, similar to that reported in Scheme 4, in which the hydrogen carbonate may play the role of nucleophile, like imidazole. However, in this mechanism the carboxylate group does not play any role so it cannot explain the different behaviour observed, for example, in the cases of 2-, 3- and 4-piperidinecarboxylic acid (Table 3, entries 3, 5 and 6).

Further support for our hypotheses was obtained by means of a computational approach. We used sarcosine as a model amino acid, together with MVK and 4-nitrobenzaldehyde as the model ketone and aldehyde, respectively (Scheme 6). Calculations performed at different levels of theory (semi-empirical PM3/COSMO and ab initio 3-21G/ COSMO; dimethyl sulfoxide was assumed as the model solvent; the data are collected in Table 6) both predict the enaminolactone species $\mathbf{2}$ to be energetically much more stable than the corresponding open-chain iminium zwitterion $\mathbf{1}$ (by $10.2 \mathrm{kcal} \mathrm{mol}^{-1}$ for PM3 and by $31.6 \mathrm{kcal} \mathrm{mol}^{-1}$ for 3 $21 \mathrm{G})$. Interestingly, the $3-21 \mathrm{G}$ calculations suggest that the formation of $\mathbf{2}$ is energetically unfavourable with respect to the reactants (by $7.7 \mathrm{kcal} \mathrm{mol}^{-1}$ ). By contrast, semi-empirical PM3 calculations predict the formation of $\mathbf{2}$ to be slightly favoured (by $1.3 \mathrm{kcal} \mathrm{mol}^{-1}$ ). Nevertheless, both of these computational results may be compatible with the ex- perimental finding that no reaction intermediate (either enaminolactone or iminium ion) could be observed by NMR spectroscopy during kinetic experiments. In fact, even if the intermediate had an energy comparable to the reactants, its steady-state concentration would anyway be low due to a mass-action effect because of the large amount of water (as co-solvent) present in the reaction system. ${ }^{[30]}$

The computational approach has also been useful for investigating the role of the hydrogen carbonate ion in the reaction. In fact, our results clearly show that the presence of an ampholyte species (such as $\mathrm{HCO}_{3}^{-}$) in the reaction system is essential in order to obtain the product. Solvent assistance during the $\mathrm{C}-\mathrm{C}$ bond-forming step has already been hypothesized previously for these reactions. ${ }^{[9]}$ In our particular case, the interaction between the enaminolactone precursor $\mathbf{2}$ and the aldehyde should afford a zwitterionic intermediate that can give the final product via two subsequent proton exchanges with the solvent. Our calculations predict that such a zwitterionic intermediate alone is unstable and spontaneously collapses back to the reactants. However, a possible complex (3) between this zwitterion and $\mathrm{HCO}_{3}^{-}$, in which the negatively charged $\mathrm{O}$ atom of the aldehyde group stabilizes its negative charge by forming a hydrogen bond with $\mathrm{HCO}_{3}^{-}$, is predicted to be a stationary point. Nevertheless, such a complex is much less stable than the hydrogen-bonded complex $\mathbf{6}$ formed between the product and $\mathrm{HCO}_{3}^{-}$(by $26.7 \mathrm{kcalmol}^{-1}$ for PM3, by $36.3 \mathrm{kcalmol}^{-1}$ for $3-21 \mathrm{G}$ ). The intermediate complex 3 might be transformed into 6 either directly, by a concerted double-proton transfer (path $a$ ), or in a two-step process via intermediates $\mathbf{4}$ (path $b$ ) or $\mathbf{5}$ (path $c$ ). The former intermediate 4 is formed by breaking the relevant $\mathrm{C}-\mathrm{H}$ bond with subsequent proton transfer to the base $\mathrm{HCO}_{3}^{-}$, whereas the latter one, $\mathbf{5}$, is obtained by proton transfer from $\mathrm{HCO}_{3}^{-}$to the alcoholate $\mathrm{O}$ atom. It is worth noting that $\mathbf{5}$ is predicted to be a stationary point by PM3 (less stable than 3 by $2.0 \mathrm{kcal} \mathrm{mol}^{-1}$ ) but not by 3-21G (its model directly collapses to $\mathbf{6}$ ). By contrast, $\mathbf{4}$ is unambiguously 


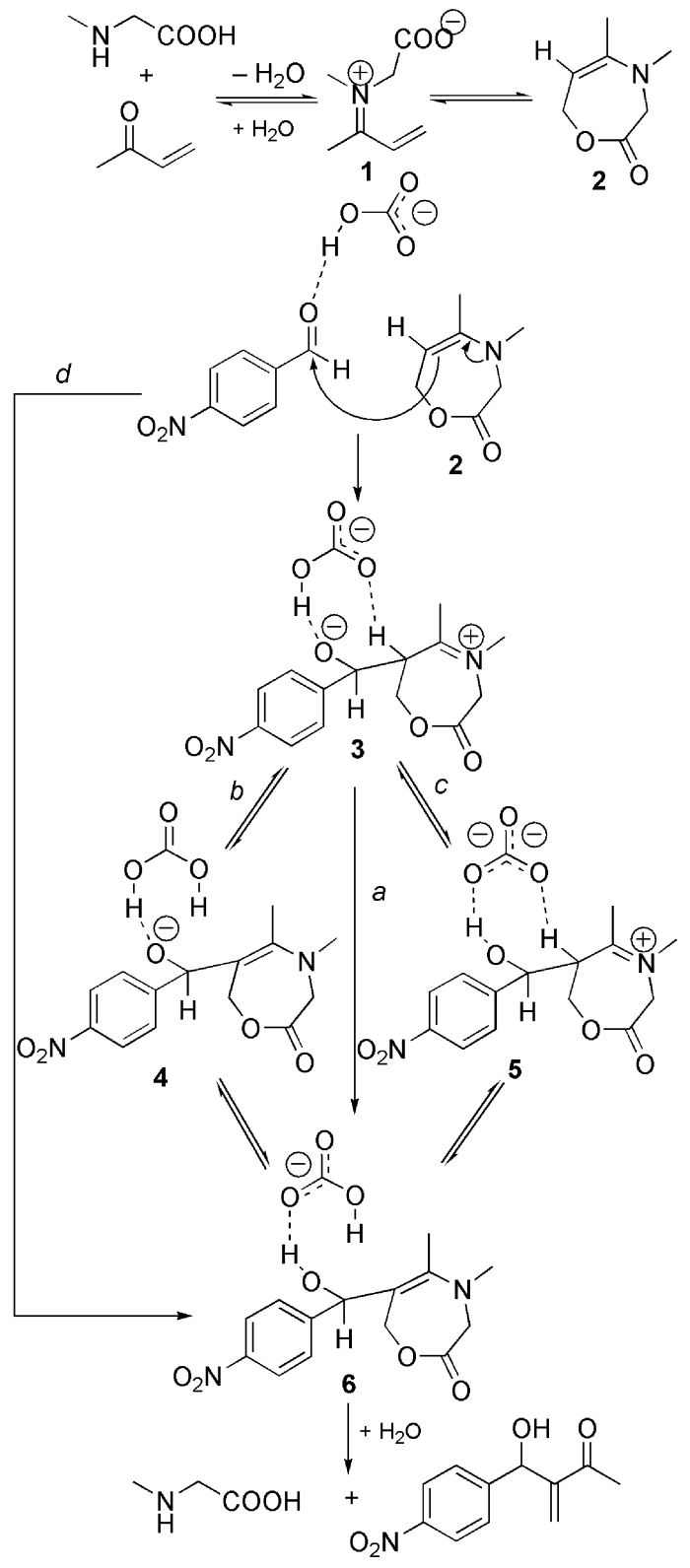

Scheme 6. Possible mechnisms for the Baylis-Hillman reaction highlighting the role of the carbonate ion, as deduced by computational methods.

predicted to be a stationary point (PM3 predicts it to be more stable than 3 by $10.8 \mathrm{kcal} \mathrm{mol}^{-1}$, whereas $3-21 \mathrm{G}$ predicts nearly the same energy as 3 ). Finally, a further alternative pathway to 6 might be a fully concerted $\mathrm{C}-\mathrm{C}$ bondformation double-proton transfer process from a suitable hydrogen-bonded encounter complex between the reactants (path $d$ ).

Next we performed some IRC (intrinsic reaction coordinate) calculations to obtain a more detailed picture of the reaction course. Computations were performed only at the PM3/COSMO level of theory (the results are represented in Figure 3). The formation of intermediate complex 3 is predicted to occur through a late transition state, the incipient $\mathrm{C}-\mathrm{C}$ bond having a length of approximately $1.80 \AA$.
Table 6. Calculated energies for the model reaction.

\begin{tabular}{|c|c|c|c|c|}
\hline & \multicolumn{2}{|c|}{$\mathrm{PM} 3 / \mathrm{COSMO}$} & \multicolumn{2}{|c|}{ 3-21G/COSMO } \\
\hline & $\begin{array}{c}\Delta H_{\mathrm{f}} \\
{\left[\mathrm{kcal} \mathrm{mol}^{-1}\right]}\end{array}$ & $\begin{array}{c}d_{\mathrm{C}-\mathrm{C}} \\
{[\AA]}\end{array}$ & $E_{\mathrm{f}}[$ Hartree $]$ & $\begin{array}{c}d_{\mathrm{C}-\mathrm{C}} \\
{[\AA]}\end{array}$ \\
\hline MVK & -33.64 & - & -228.521451 & - \\
\hline Sarcosine $e^{[a]}$ & -108.16 & - & -320.069140 & - \\
\hline $\mathrm{H}_{2} \mathrm{O}$ & -61.52 & - & -75.591790 & - \\
\hline 1 & -71.13 & - & -472.956282 & - \\
\hline 2 & -81.95 & - & -472.986612 & - \\
\hline 4-Nitrobenzaldehyde & -40.08 & - & -543.804828 & - \\
\hline $\mathrm{HCO}_{3}^{-}$ & -267.72 & - & -261.694642 & - \\
\hline 3 & -349.05 & 1.635 & -1278.462636 & 1.642 \\
\hline 4 & -359.73 & 1.549 & -1278.462770 & 1.587 \\
\hline 5 & -346.89 & 1.569 & - & - \\
\hline 6 & -386.27 & 1.519 & -1278.520531 & 1.531 \\
\hline $\mathrm{TS}^{f_{b}}$ & -335.66 & 1.596 & - & - \\
\hline $\mathrm{TS}^{\neq_{c}^{0}}$ & -333.50 & 1.590 & - & - \\
\hline $\mathrm{TS}^{\neq} d^{[\mathrm{b}]}$ & -331.14 & 2.068 & - & - \\
\hline
\end{tabular}

[a] Calculations predict the neutral tautomer to be a little more stable than the corresponding zwitterion. [b] The model was built by fixing the $\mathrm{C}-\mathrm{C}$ distance at $2.068 \AA$.

This transition state is less stable than $\mathbf{3}$ by only $1.4 \mathrm{kcal} \mathrm{mol}^{-1}$. Therefore, the real activation energy for the overall reaction should be associated with proton-transfer processes leading either to $\mathbf{4}$ (the relevant transition state $\mathbf{T S}^{\neq}{ }_{\boldsymbol{b}}$ is located at ca. $11.6 \mathrm{kcalmol}^{-1}$ above $\mathbf{3}$ ) or $\mathbf{5}$ (the relevant transition state $\mathbf{T S}^{{ }^{*}}{ }_{c}$ is located at ca. $12.6 \mathrm{kcal} \mathrm{mol}^{-1}$ above 3). Notably, no first-order saddle point was found for the concerted double-proton transfer. Therefore calculations seem to rule out the occurrence of a direct conversion of $\mathbf{3}$ into $\mathbf{6}$. For each model 4, $\mathbf{5}$ and $\mathbf{6}$, a gradual increase in the length of the newly formed $\mathrm{C}-\mathrm{C}$ bond increases the energy of the model up to a $\mathrm{C}-\mathrm{C}$ distance of around $2.4 \AA$. Any further lengthening of the bond causes the models to collapse back to the reactants. Energy curves relevant to $\mathbf{3}$ and $\mathbf{6}$ cross each other at a $\mathrm{C}-\mathrm{C}$ distance of around $2.07 \AA$. However, by fixing the $\mathrm{C}-\mathrm{C}$ distance at this value, proton exchange between the two mod-

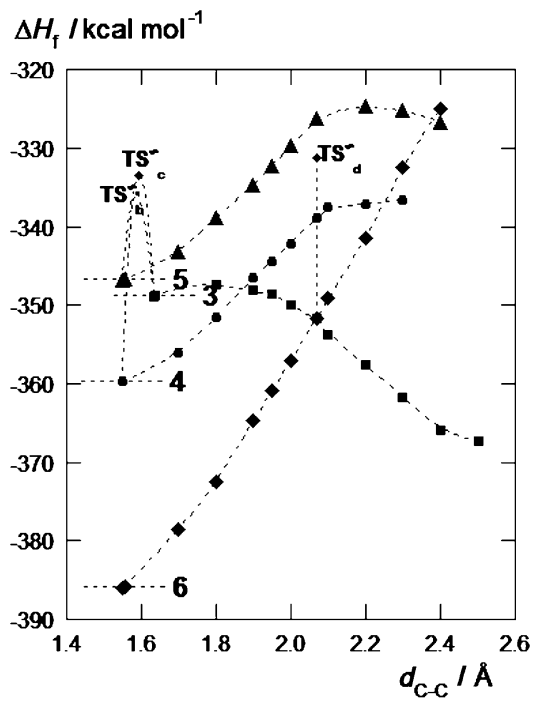

Figure 3. IRC plot for the Baylis-Hillman reaction, as calculated at the PM3/COSMO level of theory. 
els is predicted to occur at a higher activation energy $\left(\mathbf{T S}^{\neq}{ }_{d}\right)$ than the conversion of $\mathbf{3}$ into $\mathbf{4}$. Therefore the possible occurrence of a fully concerted process leading directly from the reactants' encounter complex to $\mathbf{6}$ seems to be ruled out too. Computational evidence seems on the whole to suggest that the hydrogen carbonate ion may have a double role in the reaction course: i) driving the approach between the reactants by stabilization of the encounter complex and of the zwitterion intermediate by hydrogen-bond formation and ii) acting as a base, which breaks the relevant $\mathrm{C}-\mathrm{H}$ bond of the zwitterionic intermediate, rather than as a bifunctional proton donor-acceptor catalyst.

\section{Conclusions}

In summary, we have reported that secondary amino acids such as proline, sarcosine, pipecolinic acid and homoproline in the presence of sodium hydrogen carbonate catalyse the Baylis-Hillman reaction between methyl or ethyl vinyl ketone and aryl aldehydes to give the corresponding adducts in good yields. Of these amino acids, proline was found to be the most efficient catalyst and the data obtained show, for the first time, that it may act as a bifunctional catalyst: ${ }^{[32]}$ the amino group attacks MVK to give the zwitterionic iminium species which undergoes intramolecular nucleophilic attack by the carboxylate group to give the bicyclic enaminolactone species as an intermediate. The hydrogen carbonate ion seems to provide hydrogen-bond assistance in the $\mathrm{C}-\mathrm{C}$ bond formation step. Quantum mechanical calculations support the mechanistic hypotheses proposed. Although no enantioselectivity was observed, this mechanism may have stereochemical implications in intramolecular Baylis-Hillman reactions and investigations on this topic will be presented in the due course.

\section{Experimental Section}

General: The NMR spectra were recorded with a Bruker $300 \mathrm{MHz}$ spectrometer using $\mathrm{CDCl}_{3}$ as solvent. FTIR spectra were recorded with a Shimadzu FTIR 8300 infrared spectrometer. C, H and N contents were determined by combustion analysis using a Fisons EA 1108 elemental analyser. Products, except those reported in Table 1, entries 6, 8, 9, 13,14,17, 19 and 20, are known compounds and showed spectroscopic and analytical data in agreement with their structures.

General Procedure for the Baylis-Hillman Reactions: Proline $(0.1 \mathrm{mmol})$ and $\mathrm{NaHCO}_{3}(0.25 \mathrm{mmol})$ were added to a mixture of the corresponding aryl aldehyde $(1.0 \mathrm{mmol})$ and methyl vinyl ketone $(3.0 \mathrm{mmol})$ in DMF $(900 \mu \mathrm{L})$ and $\mathrm{H}_{2} \mathrm{O}(100 \mu \mathrm{L})$. The reaction mixture was stirred at $40^{\circ} \mathrm{C}$ for the time indicated in Table 1 . The reaction was quenched by adding water and extracted with dichloromethane. The organic layers were collected, washed with brine and dried with $\mathrm{Na}_{2} \mathrm{SO}_{4}$. The solvent was removed under reduced pressure and the crude product was purified by chromatography (petroleum ether/ethyl acetate). In the case of ethyl vinyl ketone, the reaction was carried out on larger scale $(5.0 \mathrm{mmol}$ aldehyde).

3-[(3-Bromophenyl)(hydroxy)methyl]but-3-en-2-one (Table 1, Entry 6): Yield $179 \mathrm{mg}(70 \%)$. Oil. ${ }^{1} \mathrm{H}$ NMR $\left(\mathrm{CDCl}_{3}, 300 \mathrm{MHz}\right): \delta=$
7.37 (s, $1 \mathrm{H}), 7.26$ (d, $J=8.4 \mathrm{~Hz}, 1 \mathrm{H}), 7.15$ (d, $J=8.4 \mathrm{~Hz}, 1 \mathrm{H})$, $7.06(\mathrm{t}, J=8.4 \mathrm{~Hz}, 1 \mathrm{H}), 6.09(\mathrm{~s}, 1 \mathrm{H}), 5.93(\mathrm{~s}, 1 \mathrm{H}), 5.42(\mathrm{~s}, 1 \mathrm{H})$, $3.64(\mathrm{~s}, 1 \mathrm{H}, \mathrm{OH}), 2.18(\mathrm{~s}, 3 \mathrm{H}) \mathrm{ppm} .{ }^{13} \mathrm{C} \mathrm{NMR}\left(\mathrm{CDCl}_{3}, 75 \mathrm{MHz}\right)$ : $\delta=199.8,149.2,144.0,130.4,129.7,129.3,126.8,125.1,122.2$, 71.4, 26.2 ppm. FTIR (neat): $\tilde{v}_{\max }=3418,1674,1627,1570,1473$, $1365,1297,1186,1041,975,842,782,699 \mathrm{~cm}^{-1} \cdot \mathrm{C}_{11} \mathrm{H}_{11} \mathrm{BrO}_{2}$ (255.11): calcd. C 51.79, H 4.35; found C 51.85, H 4.40.

3-[(3-Chlorophenyl)(hydroxy)methyl]but-3-en-2-one (Table 1, Entry 8): Yield $166 \mathrm{mg}(79 \%)$. Oil. ${ }^{1} \mathrm{H} \mathrm{NMR}\left(\mathrm{CDCl}_{3}, 300 \mathrm{MHz}\right): \delta=$ $7.31(\mathrm{~s}, 1 \mathrm{H}), 7.20(\mathrm{~m}, 3 \mathrm{H}), 6.18(\mathrm{~s}, 1 \mathrm{H}), 6.00(\mathrm{~s}, 1 \mathrm{H}), 5.52(\mathrm{~s}, 1 \mathrm{H})$, 3.65 (s, $1 \mathrm{H}, \mathrm{OH}), 2.28$ (s, $3 \mathrm{H}) \mathrm{ppm} .{ }^{13} \mathrm{C} \mathrm{NMR}\left(\mathrm{CDCl}_{3}, 75 \mathrm{MHz}\right): \delta$ $=199.9,149.3,143.7,134.0,129.5,127.6,126.9,126.5,124.6,71.6$, $26.2 \mathrm{ppm}$. FTIR (neat): $\tilde{v}_{\max }=3422,1674,1628,1596,1575,1474$, $1365,1298,1191,1042,977,884,785,697 \mathrm{~cm}^{-1} \cdot \mathrm{C}_{11} \mathrm{H}_{11} \mathrm{ClO}_{2}$ (210.66): calcd. C 62.72, H 5.26; found C 62.80, H 5.30.

3-[(2-Cyanophenyl)(hydroxy)methyl]but-3-en-2-one (Table 1, Entry 9): Yield $169 \mathrm{mg}(84 \%)$. Light-yellow solid, m.p. $133-136{ }^{\circ} \mathrm{C}$. ${ }^{1} \mathrm{H}$ NMR $\left(\mathrm{CDCl}_{3}, 300 \mathrm{MHz}\right): \delta=7.90-7.79(\mathrm{~m}, 2 \mathrm{H}), 7.52-7.34$ (m, $2 \mathrm{H}), 6.13$ (s, $1 \mathrm{H}), 6.00$ (s, $1 \mathrm{H}), 5.71(\mathrm{~s}, 1 \mathrm{H}), 2.42$ (s, $3 \mathrm{H}) \mathrm{ppm}$. ${ }^{13} \mathrm{C} \mathrm{NMR}\left(\mathrm{CDCl}_{3}, 75 \mathrm{MHz}\right): \delta=199.1,171.4,146.1,145.9,131.9$, 131.0, 128.3, 126.1, 123.7, 123.5, 55.4, $26.1 \mathrm{ppm}$. FTIR (neat): $\tilde{\mathrm{v}}_{\max }$ $=3390,2226,1674,1615,1511,1470,1367,1267,958,746 \mathrm{~cm}^{-1}$. $\mathrm{C}_{12} \mathrm{H}_{11} \mathrm{NO}_{2}$ (201.22): calcd. C 71.63, $\mathrm{H}$ 5.51, N 6.96; found $\mathrm{C}$ 71.70, H 5.49, N, 7.01.

3-[(2-Chloro-5-nitrophenyl)(hydroxy)methyl]but-3-en-2-one (Table 1, Entry 13): Yield $197 \mathrm{mg}$ (77\%). Off-white solid, m.p. 101-104 ${ }^{\circ} \mathrm{C}$. ${ }^{1} \mathrm{H}$ NMR $\left(\mathrm{CDCl}_{3}, 300 \mathrm{MHz}\right): \delta=8.45(\mathrm{~d}, J=2.6 \mathrm{~Hz}, 1 \mathrm{H}), 8.10$ (dd, $J=8.8$ and $2.6 \mathrm{~Hz}, 1 \mathrm{H}), 7.52(\mathrm{~d}, J=8.8 \mathrm{~Hz}, 1 \mathrm{H}), 6.48(\mathrm{~s}, 1$ H), 5.99 (s, $1 \mathrm{H}), 5.73$ (s, $1 \mathrm{H}), 3.64(\mathrm{~s}, 1 \mathrm{H},-\mathrm{OH}), 2.41$ (s, $3 \mathrm{H}) \mathrm{ppm}$. ${ }^{13} \mathrm{C} \mathrm{NMR}\left(\mathrm{CDCl}_{3}, 75 \mathrm{MHz}\right): \delta=200.1,147.6,146.9,140.9,139.2$, $130.3,127.9,123.6,123.5,68.4,26.1 \mathrm{ppm}$. FTIR (neat): $\tilde{v}_{\max }=$ 3508, 2922, 2853, 1666, 1524, 1461, 1346, 1274, 1033, $742 \mathrm{~cm}^{-1}$. $\mathrm{C}_{11} \mathrm{H}_{10} \mathrm{ClNO}_{4}$ (255.65): calcd. C 51.68, H 3.94, N, 5.48; found $\mathrm{C}$ 51.73, H 3.99, N 5.52.

3-[(2,6-Dichlorophenyl)(hydroxy)methyl]but-3-en-2-one (Table 1, Entry 14): Yield $220 \mathrm{mg}(90 \%)$. Oil. ${ }^{1} \mathrm{H} \mathrm{NMR}\left(\mathrm{CDCl}_{3}, 300 \mathrm{MHz}\right): \delta$ $=7.19(\mathrm{~d}, J=8.5 \mathrm{~Hz}, 2 \mathrm{H}), 7.04(\mathrm{t}, J=8.5 \mathrm{~Hz}, 1 \mathrm{H}), 6.24(\mathrm{t}, J=$ $1.9 \mathrm{~Hz}, 1 \mathrm{H}), 6.15(\mathrm{~d}, J=1.9 \mathrm{~Hz}, 1 \mathrm{H}), 5.88(\mathrm{~d}, J=1.9 \mathrm{~Hz}, 1 \mathrm{H})$, 3.53 (s, $1 \mathrm{H}, \mathrm{OH}), 2.27$ (s, $3 \mathrm{H}) \mathrm{ppm} .{ }^{13} \mathrm{C} \mathrm{NMR}\left(\mathrm{CDCl}_{3}, 75 \mathrm{MHz}\right)$ : $\delta=199.7,147.3,135.3,135.2,129.1,126.4,69.5,26.4$ ppm. FTIR (neat): $\tilde{v}_{\max }=3422,3002,2937,2228,1675,1627,1579,1562,1436$, $1365,1308,1183,1088,1018,974,842,780,737 \mathrm{~cm}^{-1} \cdot \mathrm{C}_{11} \mathrm{H}_{10} \mathrm{Cl}_{2} \mathrm{O}_{2}$ (245.10): calcd. C 53.90, H 4.11; found C 53.98, H, 4.07.

3-[(3-Methoxyphenyl)(hydroxy)methyl]but-3-en-2-one (Table 1, Entry 17): Yield $122 \mathrm{mg}(59 \%)$. Oil. ${ }^{1} \mathrm{H} \mathrm{NMR}\left(\mathrm{CDCl}_{3}, 300 \mathrm{MHz}\right): \delta$ $=7.21(\mathrm{t}, J=8.1 \mathrm{~Hz}, 1 \mathrm{H}), 6.90-6.86(\mathrm{~m}, 2 \mathrm{H}), 6.77(\mathrm{ddd}, J=8.1$, 2.1 and $1.5 \mathrm{~Hz}, 1 \mathrm{H}), 6.16(\mathrm{~s}, 1 \mathrm{H}), 5.98(\mathrm{~s}, 1 \mathrm{H}), 5.55(\mathrm{~s}, 1 \mathrm{H}), 3.76$ (s, $3 \mathrm{H}), 2.29$ (s, $3 \mathrm{H}) \mathrm{ppm} .{ }^{13} \mathrm{C} \mathrm{NMR}\left(\mathrm{CDCl}_{3}, 75 \mathrm{MHz}\right): \delta=200$, $159.5,149.8,143.2,129.3,126.6,118.8,113.0,112.0,72.2,55.1$, 26.4 ppm. FTIR (neat): $\tilde{v}_{\max }=3438,1674,1600,1585,1488,1455$, 1435, 1364, 1188, 1040, 877, $782 \mathrm{~cm}^{-1} \cdot \mathrm{C}_{12} \mathrm{H}_{14} \mathrm{O}_{3}$ (206.24): calcd. $\mathrm{C}$ 69.88, H 6.84; found C 69.80, H 6.87.

2-[(4-Cyanophenyl)(hydroxy)methyl]pent-1-en-3-one (Table 1, Entry 19): Yield $174 \mathrm{mg}(81 \%)$. Oil. ${ }^{1} \mathrm{H}$ NMR $\left(\mathrm{CDCl}_{3}, 300 \mathrm{MHz}\right): \delta$ $=7.50(\mathrm{~d}, J=8.5 \mathrm{~Hz}, 2 \mathrm{H}), 7.40(\mathrm{~d}, J=8.5 \mathrm{~Hz}, 2 \mathrm{H}), 6.17(\mathrm{~s}, 1$ $\mathrm{H}), 6.00(\mathrm{~s}, 1 \mathrm{H}), 5.56(\mathrm{~s}, 1 \mathrm{H}), 3.86(\mathrm{~s}, 1 \mathrm{H}, \mathrm{OH}), 2.62(\mathrm{q}, J=$ $7.2 \mathrm{~Hz}, 2 \mathrm{H}), 0.94(\mathrm{t}, J=7.2 \mathrm{~Hz}, 3 \mathrm{H}) \mathrm{ppm} .{ }^{13} \mathrm{C} \mathrm{NMR}\left(\mathrm{CDCl}_{3}\right.$, $75 \mathrm{MHz}): \delta=202.2,148.5,147.3,131.8,127.0,125.6,118.5,110.6$, 71.4, 31.1, 7.6 ppm. FTIR (neat): $\tilde{v}_{\max }=3462,2228,1675,1607$, 1502, 1409, 1377, 1102, 1018, 979, $828 \mathrm{~cm}^{-1} . \mathrm{C}_{13} \mathrm{H}_{13} \mathrm{NO}_{2}$ (215.25): calcd. C 72.54, H 6.09, N 6.51; found C 72.60, H 6.13, N 6.48. 
2-[4-(Trifluoromethylphenyl)(hydroxy)methyl]pent-1-en-3-one (Table 1, Entry 20): Yield $207 \mathrm{mg}(80 \%)$. Oil. ${ }^{1} \mathrm{H}$ NMR $\left(\mathrm{CDCl}_{3}\right.$, $300 \mathrm{MHz}): \delta=7.57(\mathrm{~d}, J=8.1 \mathrm{~Hz}, 2 \mathrm{H}), 7.46(\mathrm{~d}, J=8.1 \mathrm{~Hz}, 2 \mathrm{H})$, $6.20(\mathrm{~s}, 1 \mathrm{H}), 5.97(\mathrm{~s}, 1 \mathrm{H}), 5.62(\mathrm{~s}, 1 \mathrm{H}), 3.59$ (s, 1 H, OH), 2.69 $(\mathrm{q}, J=7.2 \mathrm{~Hz}, 2 \mathrm{H}), 1.03(\mathrm{t}, J=7.2 \mathrm{~Hz}, 3 \mathrm{H}) \mathrm{ppm} .{ }^{13} \mathrm{C} \mathrm{NMR}$ $\left(\mathrm{CDCl}_{3}, 75 \mathrm{MHz}\right): \delta=202.9,148.8,145.7,126.9,126.7,126.3$, 125.7, $125.2\left(\mathrm{~m}, \mathrm{CF}_{3}\right), 72.4,31.4,7.8 \mathrm{ppm}$. FTIR (neat): $\tilde{v}_{\max }=$ $3425,1674,1619,1415,1326,1124,1067,1017,979 \mathrm{~cm}^{-1}$. $\mathrm{C}_{13} \mathrm{H}_{13} \mathrm{~F}_{3} \mathrm{O}_{2}$ (258.24): calcd. C 60.46, H 5.07; found $\mathrm{C} 60.52, \mathrm{H}$ 5.11

Kinetic Measurements: 4-Nitrobenzaldehyde $(0.5 \mathrm{mmol})$, proline $(5$, 7.5 or $10 \mathrm{~mol}-\%)$, MVK (1.5 mmol), $\mathrm{NaHCO}_{3} \quad(25 \mathrm{~mol}-\%)$, [D $\mathrm{D}_{6}$ DMSO $(0.45 \mathrm{~mL})$ and $\mathrm{D}_{2} \mathrm{O}(0.05 \mathrm{~mL})$ were placed in a NMR tube. A small magnetic bar was added to each tube. The tubes were then placed in a bath at $40{ }^{\circ} \mathrm{C}$ and the reaction mixtures stirred. At regular intervals the magnetic bars were removed and ${ }^{1} \mathrm{H}$ NMR spectra recorded.

Supporting Information (see also the footnote on the first page of this article): Computational details and Cartesian matrices for the optimized structures of models 1-6.

\section{Acknowledgments}

Financial support from the University of Palermo (Funds for Selected Topics) and the Italian Ministero dell'Università e della Ricerca (MIUR) within the National Project "Catalizzatori, metodologie e processi innovativi per il regio- e stereocontrollo delle sintesi organiche" is gratefully acknowledged.

[1] D. Basavaiah, K. Venkateswara Rao, R. Jannapu Reddy, Chem. Soc. Rev. 2007, 36, 1581-1588.

[2] G. Masson, C. Housseman, J. Zhu, Angew. Chem. Int. Ed. 2007, 46, 4614-4628.

[3] D. Basavaiah, A. Jaganmohan Rao, T. Satyanarayana, Chem. Rev. 2003, 103, 811-891.

[4] P. Langer, Angew. Chem. Int. Ed. 2000, 39, 3049-3052.

[5] D. Basavaiah, P. D. Rao, R. S. Hyma, Tetrahedron 1996, 52, 8001-8062.

[6] S. E. Drewes, G. H. P. Roos, Tetrahedron 1988, 44, 4653-4670.

[7] K. Morita, Z. Suzuki, H. Hirose, Bull. Chem. Soc. Jpn. 1968, 41,2815

[8] V. K. Aggarwal, I. Emme, S. Y. Fulford, J. Org. Chem. 2003, 68, 692-700.

[9] V. K. Aggarwal, S. Y. Fulford, G. C. Lloyd-Jones, Angew. Chem. Int. Ed. 2005, 44, 1706-1708.

[10] K. E. Price, S. J. Broadwater, B. J. Walker, D. T. McQuade, J. Org. Chem. 2005, 70, 3980-3987.

[11] K. E. Price, S. J. Broadwater, H. M. Jung, D. T. McQuade, Org Lett. 2005, 7, 147-150.

[12] R. Gatri, M. M. El Gaïed, Tetrahedron Lett. 2002, 43, 78357836.

[13] S. Luo, X. Mi, P. G. Wang, J.-P. Cheng, Tetrahedron Lett. 2004, $45,5171-5174$.
[14] S. Luo, P. G. Wang, J.-P. Cheng, J. Org. Chem. 2004, 69, 555558.

[15] M. Shi, J.-K. Jiang, C.-Q. Li, Tetrahedron Lett. 2002, 43, $127-$ 130.

[16] H. J. Davies, A. M. Ruda, N. C. O. Tomkinson, Tetrahedron Lett. 2007, 48, 1461-1464.

[17] C. E. Aroyan, M. M. Vasbinder, S. J. Miller, Org. Lett. 2005, 7, 3849-3851.

[18] S.-H. Chen, B.-C. Hong, C.-F. Su, S. Sarshar, Tetrahedron Lett. 2005, 46, 8899-8903.

[19] J. E. Imbriglio, M. M. Vasbinder, S. J. Miller, Org. Lett. 2003, $5,3741-3743$

[20] H. Tang, G. Zhao, Z. Zhou, Q. Zhou, C. Tang, Tetrahedron Lett. 2006, 47, 5717-5721.

[21] H. Tang, P. Gao, G. Zhao, Z. Zhou, L. He, C. Tang, Catal. Commun. 2007, 8, 1811-1814.

[22] H. Tang, G. Zhao, Z. Zhou, P. Gao, L. He, C. Tang, Eur. J. Org. Chem. 2008, 47, 126-135.

[23] J. Vesely, P. Dziedzic, A. Córdova, Tetrahedron Lett. 2007, 48, 6900-6904.

[24] N. Utsumi, H. Zhang, F. Tanaka, C. F. Barbas III, Angew. Chem. Int. Ed. 2007, 46, 1878-1880.

[25] a) M. Gruttadauria, S. Riela, P. Lo Meo, F. D'Anna, R. Noto, Tetrahedron Lett. 2004, 45, 6113-6116; b) M. Gruttadauria, S. Riela, C. Aprile, P. Lo Meo, F. D’Anna, R. Noto, Adv. Synth. Catal. 2006, 348, 82-92.

[26] F. Giacalone, M. Gruttadauria, A. Mossuto Marculescu, R. Noto, Tetrahedron Lett. 2007, 48, 255-259.

[27] M. Gruttadauria, F. Giacalone, A. Mossuto Marculescu, P. Lo Meo, S. Riela, R. Noto, Eur. J. Org. Chem. 2007, 46884698.

[28] C. Aprile, F. Giacalone, M. Gruttadauria, A. Mossuto Marculescu, J. D. Revell, H. Wennemers, Green Chem. 2007, 9, 1328 1334.

[29] Determined by chiral column chromatography: OD-H column, hexane/2-propanol, 95:5, $1 \mathrm{~mL} / \mathrm{min}, 30.3$ and $33.2 \mathrm{~min}$

[30] Noticeably, Aggarwal et al. ${ }^{[9]}$ reported that no intermediate products were detected by NMR in the Baylis-Hillman reaction between ethyl acrylate and benzaldehyde catalysed by quinuclidine. We carried out several ${ }^{1} \mathrm{H}$ NMR experiments by mixing MVK and proline in different ratios both in $\left[\mathrm{D}_{6}\right] \mathrm{DMSO}$ and $\left[\mathrm{D}_{6}\right] \mathrm{DMSO} / \mathrm{D}_{2} \mathrm{O}$, however no intermediate species were detected. Although the formation of enaminolactone has not been evidenced by NMR experiments, this cannot be considered as definite proof that it was not formed as its amount at equilibrium is possibly below the detection limit of NMR spectroscopy. Under these circumstances, calculations confidently provided reliable support for its formation.

[31] For instance, the carboxylate group may attack the electrophilic carbon atom of an iminium ion to form an oxazolidinone species, see: N. Zotova, A. Franzke, A. Armstrong, D. G. Blackmond, J. Am. Chem. Soc. 2007, 129, 15100-15101.

[32] For recent examples of bifunctional catalysts in asymmetric Morita-Baylis-Hillman and aza-Morita-Baylis-Hillman reactions, see: a) J. Wang, H. Li, X. Yu, L. Zu, W. Wang, Org. Lett. 2005, 7, 4293-4296; b) K. Matsui, S. Takizawa, H. Sasai, J. Am. Chem. Soc. 2005, 127, 3680-3681.

Received: November 26, 2007 Published Online: February 6, 2008 